Margitics Ferenc*

\title{
A DISZFUNKCIONÁLIS ATTITÚDÖK, MEGKÜZDÉSI STRATÉGIÁK ÉS AZ ATTRIBÚCIÓS STÍLUS ÖSSZEFÜGGÉSE A SZUBKLINIKUS DEPRESSZIÓS TÜNETEGYÜTTESSEL FŐISKOLAI HALLGATÓKNÁL
}

Kutatásunk során arra kerestünk választ, hogy nem klinikai populációhoz tartozó fóiskolai hallgatók körében milyen mértékben mutatható ki a szubklinikus depressziós tünetegyüttes és az ezzel összefüggó diszfunkcionális attitűdök jelenléte, milyen megküzdési stratégia preferenciák alakultak ki náluk, s milyen attribúciós stílus jellemzi óket. A vizsgálatban 681 hallgató vett részt, köztük 465 nó és 216 férfi volt. A vizsgálati csoportba kerültek azok a hallgatók, akik a Beck-féle Depresszió Skálán elért eredményeik alapján a minta negyedik kvartilisébe estek (170 fố: 128 nő, 42 férfi). A kontrollcsoportot alkották azok a hallgatók, akik a minta első kvartilisébe kerültek (204fő: 118 nô, 86 férfi). A vizsgálat eredményei azt mutatják, hogy a depressziós tünetegyüttes elófordulása a fóiskolai populációban nem tér el jelentósen az irodalomban jelzett arányoktól, bár kissé magasabb értékeket mutat. A vizsgálati csoport tagjaira a diszfunkcionális attitúdök közül elsôsorban a külsố kontroll attitûd volt jellemzố. A problémaközpontú megküzdési módokat tekintve a kognitív átstrukturálás alacsonyabb és a külső alkalmazkodás magasabb szintjét tudtuk kimutatni náluk, mint a kontrollcsoport tagjainál. Az érzelemközpontú megküzdési módok közül az érzelmi indíttatású cselekvés és a visszahúzódás előnyben részesítése jellemzi ôket. Az attribúciós stílusuk pesszimista.

Kulcsszavak: szubklinikus depressziós tünetegyüttes, diszfunkcionális attitúdök, megküzdési stratégiák, attribúciós stílus

\section{BEVEZETÉS}

Kopp és mtsai (1997) 1988-ban és 1995-ben a magyar lakosság körében végzett vizsgálataik eredményeként megállapították, hogy a magyar lakosság testi egészségromlásának legfontosabb pszichológiai háttértényezóje a depressziós tünetegyüttes.

Nemzetközi és hazai kutatások szerint a depresszió prevalenciája világszerte $7-15 \%$ körül mozog. Weissman és mtsai több országra kiterjedố kutatásai azt mutatják, hogy az unipoláris depresszió prevalenciája 1915 óta világszerte növekszik, és a depresszió kialakulása is egyre korábbi átlagéletkorra tolódik. Az USA-ban ez jelenleg a 27. év (id. Comer 2003).

* Margitics Ferenc, 4400 Nyíregyháza, Sóstói út 31/B

E-mail: margif@zeus.nyf.hu 
A depresszió általános tünetei a következók (Szádóczky 2001a; Beck és mtsai 2001):

- az érzelmi élet területén: szomorúság, anhedónia, búntudat, szégyenérzet, szorongás;

- motivációs területen: a pozitív motiváció elvesztése, fokozott függőség;

- kognitív területen: a percepció zavara (környezetének elsósorban a negatív aspektusait észleli, a világot unalmasnak, szegényesnek, színtelennek látja), problémákkal való elárasztottság érzése, döntésképtelenség, önkritizálás, abszolutisztikus gondolkodás, az összpontosítás és az emlékezet zavara;

- a viselkedés területén: passzivitás, inaktivitás, elkerülés, tehetetlenség, energiacsökkenés, a gyakorlati problémák kezelési nehézségei, a szociális késztetések zavara;

- szomatikus területen: alvászavar, étvágytalanság, a szexualitás zavarai.

A lakossági mintákban önpontozó skálákkal végzett felmérések azt mutatják, hogy a depressziós tünetegyüttes előfordulása igen gyakori: a nók 18-34\%-a, a férfiak 10-19\%-a számol be depressziós tünetekról. Súlyos klinikai szintet a nók 6-11,8\%-ánál, a férfiak 2,6-5,5\%-ánál lehet megállapítani (Szádóczky 2001a).

A depressziós tünetegyüttes előfordulási gyakoriságát a 16 év feletti magyar lakosság körében Kopp és mtsai (1997) vizsgálták 1988-ban és 1995-ben végzett reprezentatív felméréseik során. 1988-ban a megkérdezettek 24,3\%-a, 1995-ben 31,8\%-a panaszkodott depressziós tünetekre. Közepesen súlyos depresszióra utaló tüneteket 1988-ban a megkérdezettek 7,5\%-ánál, 1995-ben 14,1\%-ánál találtak.

Beck szerint azoknál a személyeknél nagyobb a valószínúsége a depresszió kialakulásának, akiket diszfunkcionális attitúdök jellemeznek. Ezekre az attitúdökre jellemzó, hogy önmagukban nem jeleznek feltétlenül betegséget, sốt néhány beállítódás a társadalom fontos hajtóereje, de halmozódásuk vagy magas szintjük patológiás fejlódésre hajlamosít (id. Csorba és mtsai 1996).

A diszfunkcionális attitúdök a személynek az önmaga és a világ iránt kialakított negatív attitúdjei, amelyek olyan kognitív sémákba merevedtek, amelyhez a személy a tapasztalatait méri (Beck és mtsai 2001).

Weissman és Beck (1979), valamint Burns (1980) a következő alapvetô beállítódásokat vizsgálták, amelyek diszfunkcionálisakká válhatnak: külső elismerés igénye, szeretettség igénye, teljesítményigény, perfekcionizmus, jogos, a környezet felé irányuló fokozott elvárások, omnipotencia, fokozott altruizmus beállítottság, külsô kontroll-autonómia. 
Kopp és mtsai (1997) az országos minta alapján ezek közül a fokozott szeretetigényt és a fokozott perfekcionizmust találták jellemzónek a magyar lakosságra. Többváltozós skálázási modell alapján a diszfunkcionális attitűdök közül a következóket találták jellemzónek a depresszióra: fokozott szeretetigény, fokozott elismerésigény, fokozott teljesítményigény.

A diszfunkcionális attitúdök a depresszió kialakulásában lényeges szerepet játszhatnak. Ezeknek az attitúdöknek a képességekkel és lehetôségekkel nem arányos fokozódása depressziós tünetek megjelenéséhez vezethet. Ha a személy élete sok területén vár el túl sokat saját magától és környezetétól, és ha ô vagy környezete nem tud megfelelni fokozott elvárásainak, akkor könnyen negatívan minôsítheti saját magát, aminek egyenes következménye lehet a reménytelenség kialakulása, majd depressziós tünetek megjelenése (Kopp és Skrabski 1995).

A depressziós tünetek az ember és a környezet közötti egyensúly megbomlására utalnak, a megküzdési képességek elégtelenségét jelzik, ami megnehezíti a világ változó körülményeihez való megfelelố alkalmazkodást (Kopp 1994).

Megküzdésnek nevezzük azt a folyamatot, amikor a személy megpróbál szembeszállni a stresszel. A megküzdési képességek, a coping stratégiák azt mutatják, hogyan tud a személy a nehéz, stresszkeltó élethelyzetekkel megbirkózni. Ezek a megküzdési (coping) stratégiák a szocializáció során alakulnak ki.

A megküzdési stratégiák egy, a személyre viszonylag stabilan jellemzố megküzdési mintázatot, profilt alkotnak, amelyeknek a kialakulása számos állandó személyiségjegytôl, valamint a személy viszonylag kevésbé stabil tényezóitól függ. Ilyen kevésbé stabil tényezó a személy önértékelése, optimista, illetve pesszimista beállítottsága (Csabai és Molnár 1999).

Lazarus és Launier (1978) kétféle megküzdési formát különböztetett meg:

- problémaközpontú megküzdés: ekkor a személy a helyzetre, a problémára összpontosít, hogy megkísérelje azt megváltoztatni, hogy a jövóben el tudja kerülni;

- érzelemközpontú megküzdés: a személy ekkor azzal foglalkozik, hogy enyhítse a stresszhelyzet okozta érzelmi reakciókat, megakadályozza a negatív érzelmek elhatalmasodását. Akkor is ilyet használ a személy, ha a helyzetet nem tudja megváltoztatni.

A problémaközpontú megküzdés problémamegoldó stratégiák alkalmazását jelenti, amelyek irányulhatnak kifelé, magára a problémás helyzetre, de befelé is: ez esetben a személy önmagában változtat meg valamit, ahelyett, hogy a környezetet módosítaná. 
Lazarus (1990) szerint ezek a stratégiák az egészséges, érett személyiség jellemzôi. Patológiás konfliktusmegoldás esetén elsősorban az énvédelem, a szorongás csökkentése a cél, az énvédő vagy elhárító mechanizmusokon keresztül. A nem adaptív konfliktuskezelési stratégiák a különböző testi, mentális megbetegedések elóidézésében, fenntartásában és kiújulásában is jelentős szerepet játszanak.

Kopp és Skrabski (1995) kutatásuk során három problémaorientált, három érzelmi és egy támogatást keresố megküzdési módot különböztettek meg. Ezek a következők: problémaelemzés, kognitív átstrukturálás, alkalmazkodás, érzelmi indíttatású cselekvés, érzelmi egyensúly keresése, visszahúzódás, segítségkérés.

Lazarus és Folkman (1986) szerint egy döntés meghozatalához az érzelmi feszültség csökkentésére van szükség. Az elsó három, problémaorientált faktor a probléma elemzésére, a probléma okának befolyásolására, a kontroll megszerzésére való alkalmasságot, valamint a kognitív átstrukturálásra való képességet méri. A második három érzelmi megoldási mód, melyek akkor kerülnek elótérbe, ha a személy nem ismeri eléggé a problémát, vagy nem érzi magát képesnek a helyzet feletti kontroll megszerzésére.

Az utóbbi két évtized kutatásai rámutattak a tehetetlenséggel összefüggó depresszív múködésmód és az attribúciós stílus között fennálló kapcsolatokra. Abramson és mtsai (1989) szerint a kontrollvesztett helyzetbe került személy implicit módon felteszi magának a kérdést, hogy miért veszítette el az adott helyzetben a kontrollt. Azok a személyek, akik a kontrollvesztést belsố tényezônek („,az én hibám”), stabil oknak („,mindig így lesz") és globális, az életük minden területére kiható oknak tulajdonítják („mindent elrontok, amit csak csinálok”), hajlamosabbak a depresszióra, mint azok, akik kevésbé pesszimista attribúciós stílussal rendelkeznek (Atkinson és mtsai 1995). Metalsky és mtsai (1987) kutatásai szerint a pesszimista attribúciós stílusú diákok sokkal depresszívebbnek bizonyultak, mint azok, akik optimistább attribúciós stílussal rendelkeztek.

\section{A VIZSGÁLAT BEMUTATÁSA}

\section{A vizsgálat célja}

Kopp és mtsai (1999) rámutatnak, hogy a serdülók és a fiatal felnôttek egészsége az egészségügy elhanyagolt területét jelentik. Ez abból fakadhat, hogy ezekben a korosztályokban a kimutatható megbetegedések aránya viszonylag alacsony, ami nem hívja fel ezekre a korosztályokra a fi- 
gyelmet. Megváltozik azonban a helyzet, ha figyelembe vesszük azt a tényt, hogy mindazok az önkárosító magatartásformák, amelyek a mai legnagyobb népegészségügyi jelentőségú megbetegedések legsúlyosabb kockázati tényezóit jelentik, ebben az életkorban alakulnak ki. Ide sorolható a dohányzás, a kóros alkoholfogyasztás, a droghasználat, a mozgásszegény életmód és a kóros táplálkozási szokások.

Kopp és Skrabski (1995) egy 1989-es vizsgálatuk során magyar egyetemisták önkárosító magatartásának pszichés hátterét kutatva megállapították, hogy az egészséges magatartás az életcélok és megfeleló konfliktuskezelő stratégiák meglétének az eredménye.

Kutatásunk során arra kerestük a választ, hogy nem klinikai populációhoz tartozó főiskolai hallgatók körében, akiknek szocializációja sikeresnek mondható, milyen mértékben mutatható ki a szubklinikus depressziós tünetegyüttes és az ezzel összefüggó diszfunkcionális attitúdök jelenléte, milyen megküzdési stratégia preferenciák alakultak ki náluk, s milyen attribúciós stílus jellemzi óket.

\section{Hipotézisek}

Kutatásunk alapjául szolgáló hipotéziseink a következók voltak:

1. A depressziós tünetegyüttes összefüggést mutat a diszfunkcionális attitúdökkel. Konkrétan:

- a depressziós tünetegyüttessel jellemezhetó személyekre fokozott teljesítményigény, perfekcionizmus, fokozott szeretet- és elismerésigény jellemzó (Kopp és mtsai 1997, 1999).

2. A depressziós tünetegyüttes összefüggést mutat a megküzdési stratégiákkal. Konkrétan:

- a depressziós tünetegyüttessel jellemezhetô személyekre inkább az érzelemközpontú megküzdési módok jellemzók, ezen belül is hajlamosak a visszahúzódásra (Kopp és Skrabski 1995; Beck és mtsai 2001).

3. A depressziós tünetegyüttes összefüggést mutat az attribúciós stílussal. Konkrétan:

- a depressziós tünetegyüttessel jellemezhetố személyekre pesszimista attribúciós stílus jellemző (Metalsky és mtsai 1987). 


\section{Minta}

Az adatgyứjtés a Nyíregyházi Fóiskolán történt, minden karon véletlenszerúen kiválasztott hallgatók körében. A részvétel minden esetben önkéntes alapon, a hallgató beleegyezésével történt. Az önkitöltéses kérdóíveket elôadás keretében, a kutatók irányításával vettük fel.

A vizsgálatban 700 fóiskolai hallgató vett részt, közülük 681 főnek volt értékelhető a kitöltött kérdőíve (465 nó, 216 férfi). A szakok szerinti megoszlás a következóképpen alakult: 225 fó humán szakos tanár, 125 reál szakos tanár, 125 gazdasági szakos, 74 tanító szakos hallgató, 70 szociálpedagógus és 62 múvészeti tanár szakos hallgató. Az életkor átlaga 19,98 (szórás 1,51), a medián értéke 20 év volt.

\section{A kutatás során használt vizsgálati eszközök}

\section{Aktuális depressziós tünetek vizsgálata}

Mérőeszköz: Beck-féle Depresszió Skála rövidített, 13 tételes szúrố változata (Beck és Beck 1972). A 13 tételes változat magyar nyelven a háziorvosi és pszichiátriai gyakorlatban alkalmazott „Depresszió, szorongás pontozó skálák" címú kiadványban hozzáférhetô (Szádóczky 2001b).

A kérdôív a depressziós tünetegyüttes következó összetevôit vizsgálja: szomorúság, reménytelenség, inszufficiencia érzés, elégedetlenség, búntudat, félelem a büntetéstól, szuicid gondolatok, érdektelenség, határozatlanság, testsémazavar, munkaképtelenség, fáradtság, étvágytalanság.

A vizsgálatok szerint a rövidített teszt mérési eredményei 0,93 mértékben korreláltak az eredeti teszttel (Rózsa és mtsai 2001). A rövidített teszttel kapott eredmények megbízhatóan átszámíthatók a teljes kérdôív pontértékeire a következó módon: rövidített összpontszám/13 × 21 .

A kérdốivben élért pontszámok határértékei a következók:

- 0-5 nincs depresszió,

- 6-11 enyhe depresszió,

- 12-15 középsúlyos depresszió,

- 15 fölött súlyos depresszió.

Attitüdök vizsgálata

Méróeszköz: Weismann-féle Diszfunkcionális Attitúd Skála magyar adaptációja (Kopp 1994).

A kérdőív a következő attitúdöket vizsgálja: külső elismerés igénye, szeretettség igénye, teljesítményigény, perfekcionizmus, jogos, a környe- 
zet felé irányuló fokozott elvárások, omnipotencia (fokozott altruizmus beállítottság), külsó kontroll-autonómia.

Megküzdési stratégiák vizsgálata

Mérőeszköz: a Folkman és Lazarus-féle konfliktusmegoldó kérdőív magyar adaptációja (Kopp 1994).

A kérdőívvel a következố konfliktuskezelési stratégiák különíthetók el: problémaelemzés, kognitív átstrukturálás, alkalmazkodás, érzelmi indíttatású cselekvés, érzelmi egyensúly keresése, visszahúzódás, segítségkérés.

\section{Attribúciós stílus vizsgálata}

Mérőeszköz: Abramson és mtsai által kidolgozott Attribúciós Stílus Kérdőív (Atkinson és mtsai 1995).

Az attribúciós stílust a következó indexek alapján ítéltük meg:

- külsố vagy belső attribúció,

- instabil vagy stabil attribúció,

- specifikus vagy globális attribúció.

A következó helyzetek megítélésére kértük fel a vizsgálati személyeket: teljesítmény megítélése (nem sikerült egy vizsga), veszteség megítélése (szakítás egy közeli baráttal).

\section{Életesemények vizsgálata}

Méróeszköz: a Cohen és mtsai által kidolgozott Középiskolás Életesemény Kérdôív Csorba és mtsai által adaptált magyar változata (Csorba és mtsai 1994). Ebból a kérdőívból csak az elmúlt fél évben történt halálesetekre adott válaszokat vizsgáltuk

\section{A vizsgálati és a kontrollcsoport kialakításának szempontjai}

A vizsgálati és a kontrollcsoport kialakításánál a Beck-féle Depresszió Skálán elért eredményeket vettük figyelembe, ezen belül is azt, hogy a minta melyik kvartilisébe kerültek a hallgatók (1. táblázat).

A vizsgálati csoportba kerültek azok a hallgatók, akik eredményeik alapján a minta negyedik kvartilisébe tartoztak (170 fớ: 128 nó, 42 férfi).

1. táblázat. A Beck-féle Depresszió Skála kvartilisei

\begin{tabular}{|l|c|c|c|c|c|}
\hline \multirow{2}{*}{} & MEDIÁN & \multicolumn{4}{|c|}{ KVARTILISEK } \\
\cline { 2 - 6 } & & elsố & második & harmadik & negyedik \\
\hline Beck-féle Depresszió Skála & 5 & $0-3$ & $4-5$ & $6-8$ & $9-39$ \\
\hline
\end{tabular}


Nem kerültek be ebbe a csoportba azok a hallgatók, akiknek az elmúlt fél év során közeli hozzátartozójuk, illetve közeli barátjuk halt meg (a gyászreakció kizárása miatt). A kontrollcsoportba kerültek azok a hallgatók, akik eredményeik alapján a minta elsó kvartilisébe tartoztak (204 fó: 118 nó, 86 férfi).

Az adatok feldolgozása SPSS for Windows 12.0 statisztikai programcsomag felhasználásával történt. A leíró statisztika és a több szempontú lineáris regresszió-elemzés mellett, a vizsgálati és a kontrollcsoport összehasonlító statisztikai vizsgálatához a kétmintás t-próbát alkalmaztunk. A háttértényezốk vizsgálatát faktoranalízis (fókomponens faktoranalízis, varimax rotációs eljárás) segítségével végeztük el.

\section{EREDMÉNYEK}

\section{A szubklinikus depressziós tünetegyüttes}

Az 1. ábra a vizsgálati és a kontrollcsoport Beck-féle Depresszió Skálán elért eredményeinek leíró statisztikáját mutatja be.

A 2. ábrán látható, hogyan alakult a depressziós tünetegyüttes (enyhe

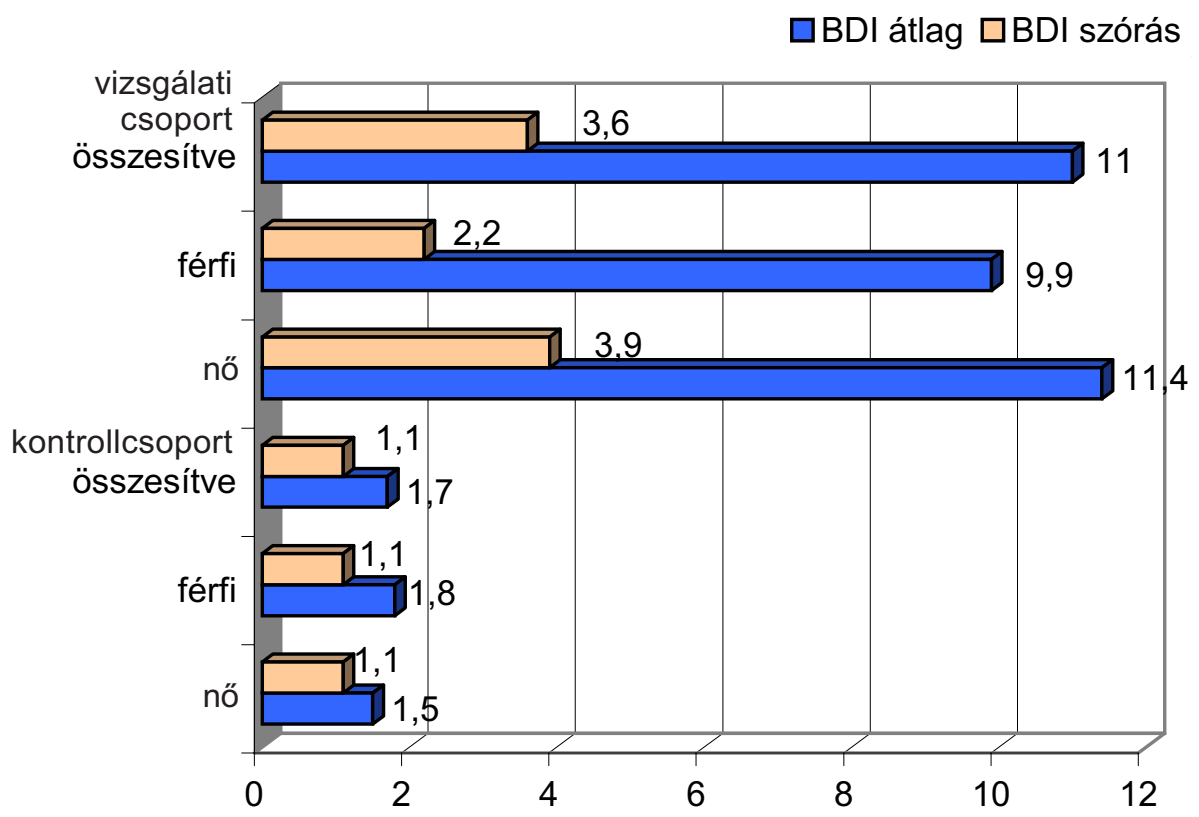

1. ábra. A vizsgálati és a kontrollcsoport Beck-féle Depresszió Skálán elért eredményeinek leíró statisztikája 


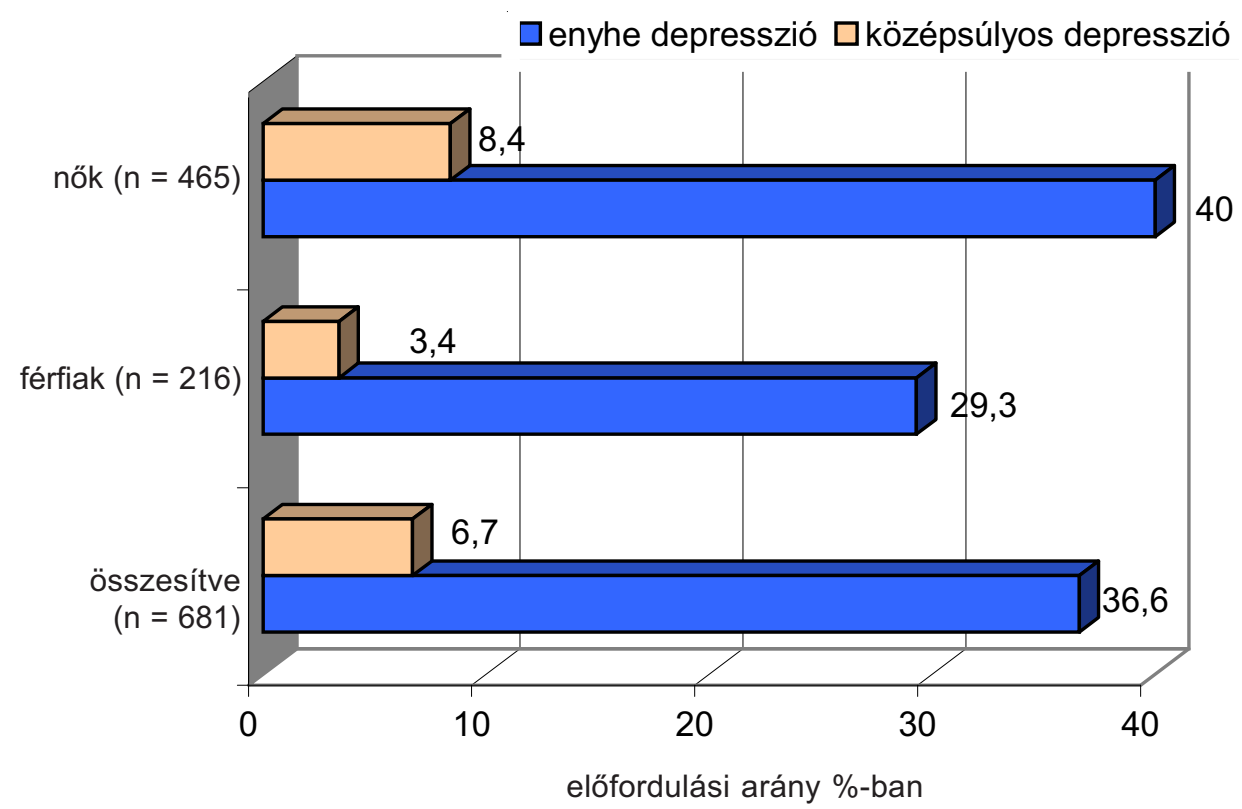

2. ábra. A szubklinikus depressziós tünetegyüttes elófordulása fóiskolai hallgatók körében

és középsúlyos forma) elófordulási aránya a vizsgált mintában (a depresszió súlyos megjelenési formája a mintában nem fordult eló).

Míg a leíró statisztikai eredmények a kontrollcsoport homogenitására utalnak, addig a vizsgálati csoport - és ezen belül különösen a nók - esetében nagyobb változékonyságot, nagyobb eltéréseket jeleznek.

Ezt erósíti meg az összehasonlító statisztikai vizsgálat, amely a vizsgálati csoportnál a nemek között szignifikáns különbséget mutatott ki $(t=2,25$, sig. $=0,026)$, miközben ez az eltérés a kontrollcsoportnál nem jelentkezett. Az eredmények arra utalnak, hogy a nóknél nemcsak gyakoribb a depressziós tünetegyüttes előfordulása, hanem a tünetek is intenzívebben jelentkezhetnek náluk.

Az egyes tünetek mintán belüli elófordulási arányát a 3. ábra mutatja be.

Az ábrából kitúnik, hogy ha az enyhe és középsúlyos megjelenési formákat egyaránt figyelembe vesszük, akkor a fóiskolás fiatalokra a depresszió tünetei közül leginkább a búntudat volt jellemzó (59,6\%). Fáradtságra (56\%) és elégedetlenségre $(55,1 \%)$ is több mint a felük panaszkodott. Ezt követi a munkaképtelenség érzése $(48 \%)$, majd a reménytelenség $(46,6 \%)$ és döntésképtelenség (42,9\%) érzése. A tünetek közül legkevésbé az öngyilkossági gondolatok (15,6\%) és a szociális visszahúzódás $(19 \%)$ jellemezte óket. 


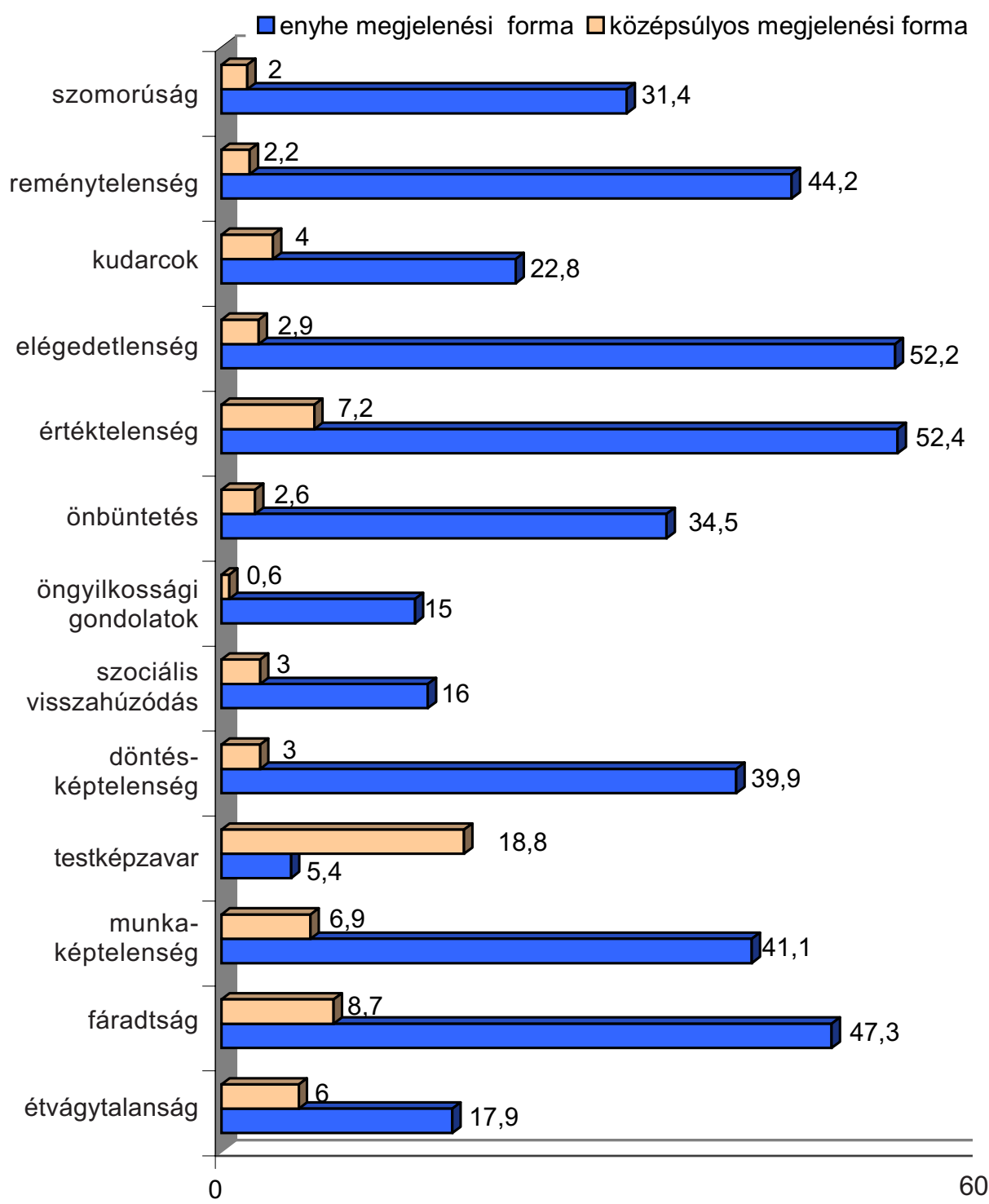

3. ábra. A Beck-féle Depresszió Skálával mérhetô tünetek előfordulási aránya a mintán belül (mindkét megjelenési formában, a minta egészéhez viszonyítva)

Ha csak a depressziós tünetek középsúlyos megjelenési formáját nézzük, akkor a testsémazavar állt az elsó helyen a tünetek közül. A fóiskolai hallgatók 18,8\%-a panaszkodott arra, hogy külseje nem elfogadható számára. Krónikus fáradtság $(8,7 \%)$ és súlyos búntudat $(7,2 \%)$, valamint 
az erófeszítésre való képtelenség (6,9\%) érzése szintén túl sok hallgatóra volt jellemző.

Megvizsgáltuk azt is, hogy az egyes tünetek mentén milyen különbség mutatkozik a két csoport között. A vizsgálatok eredményei azt mutatták, hogy minden tünet mentén szignifikáns mértékben $($ sig.<0,001) különböztek egymástól.

Elvégeztük a Beck-féle Depresszió Skála faktoranalízisét is. A vizsgálat során csak a rotált faktorokat, valamint az általános gyakorlatnak megfelelóen a 0,4-nél nem kisebb faktorsúlyokat vettük figyelembe a háttértényezók differenciálásánál (2. táblázat).

2. táblázat. A Beck-féle Depresszió Skála tételeinek strukturálódása a másodrendú faktoranalízis alapján $(1>0.40)$

\begin{tabular}{|l|c|c|c|}
\hline \multirow{2}{*}{} & \multicolumn{2}{|c|}{ Faktorok } & 3 \\
\cline { 2 - 4 } & 1 & 2 & \\
\hline Szomorúság &, 647 & & \\
Reménytelenség &, 466 & & \\
Inszufficiencia érzés &, 633 & & \\
Elégedetlenség &, 497 &, 703 & \\
Búntudat & &, 821 &, 7681 \\
Félelem a büntetéstól &, 553 & &, 592 \\
Szuicid gondolatok &, 722 & & \\
Érdektelenség & & & \\
Határozatlanság & & & \\
Testsémazavar & & & \\
Munkaképtelenség & & & \\
Fáradtság & & & \\
Étvágytalanság & & & \\
\hline
\end{tabular}

Az eddigi kutatások (Vredenburg és mtsai 1885; Volk és mtsai 1993) szerint a rövidített változat két dimenzióra bontható, testi és nem szomatikus tünetekre. A testi tüneteket a munkaképtelenség, fáradtság és étvágytalanság alkotják.

A faktoranalízis során mi is ki tudtuk mutatni a szomatikus faktort, azonban a nem szomatikus dimenzió további két, jól elkülöníthetó faktorba rendeződött. Így a vizsgált változók nálunk három faktorba rendeződtek és a teljes varianciának a 45\%-át magyarázták.

Az elsó faktor (sajátérték: 3,766), mely a teljes variancia 29\%-át magyarázta, az érdektelenséget, szomorúságot, inszufficiencia érzést, szuicid gondolatokat, elégedetlenséget és reménytelenséget emeli ki.

A második faktor (sajátérték: 1,102), mely a teljes variancia 8,5\%-át 
magyarázta, a félelmet a büntetéstól, búntudatot és határozatlanságot írja le.

A harmadik faktor (sajátérték: 1,052), mely a teljes variancia 8,1\%-át magyarázta, a fáradtságot, munkaképtelenséget, étvágytalanságot jelöli.

A faktoranalízis eredményét összevetve Molnár és Molnár (1999) teljes skálán végzett faktoranalízisének az eredményeivel (7 faktoros modell), az első faktor a tiszta depresszió faktorral, a második a búntudat faktorral mutat nagyfokú hasonlóságot.

A két csoport az összehasonlító statisztikai vizsgálatok eredménye szerint szintén jelentős mértékben különbözik egymástól a feltárt faktorok mentén is (sig.<0,001).

\section{A diszfunkcionális attitüdök}

A 4. ábra mutatja be a vizsgálati és kontrollcsoportnak a Diszfunkcionális Attitúd Skála egyes alskáláin elért átlagait.

Ezek az átlagok azt mutatják, hogy legnagyobb eltérés a két csoport között a külsó kontroll attitúdnél jelentkezett. A vizsgálati csoportra sokkal inkább jellemzőnek találtuk a külsó kontroll attitúdöt, mint a kontrollcso-

$\square$ kontrollcsoport $\square$ vizsgálati csoport

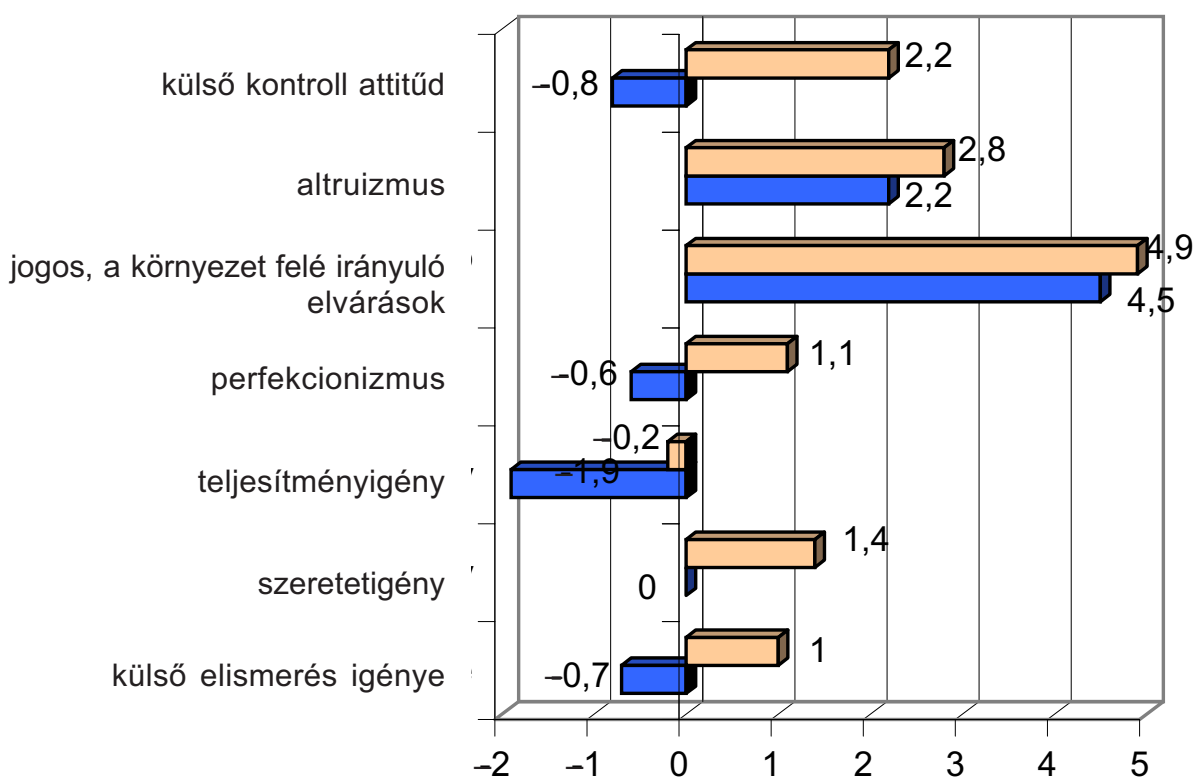

4. ábra. A vizsgálati és a kontrollcsoport Diszfunkcionális Attitúd Skálán elért átlagai 
portra. Ezt a teljesítményigény, perfekcionizmus és külső elismerésigény követi. Mind a három területen szintén a vizsgálati csoport tagjai értek el magasabb eredményeket. Jelentősebb eltérés mutatkozott még a szeretetigény területén. A környezet felé irányuló jogos elvárások és altruizmus területén kisebb eltérést találtunk, de ezek is inkább a vizsgálati csoportra jellemzók.

Az összehasonlító statisztikai vizsgálatok eredményei megerósítették a leíró statisztikai vizsgálatok eredményeit. E szerint a vizsgálati és a kontrollcsoport szignifikáns mértékben különbözött egymástól a következố diszfunkcionális attitúdök tekintetében:

- külsó elismerés igénye $(t=5,242$, sig. $<0,001)$,

- szeretetigény $(t=3,528$, sig. $<0,001)$,

- teljesítményigény $(t=3,877$, sig. $<0,001)$,

- perfekcionizmus $(t=5,074$, sig. $<0,001)$,

- külsó kontroll attitúd ( $\mathrm{t}=8,352$, sig.<0,001).

Ha a nemeknél jelentkezô eltéréseket vizsgáljuk a két csoport között, akkor a vizsgálati csoportnál két területen is jelentős, szignifikáns eltérést találunk a férfiak és a nók között (5. ábra).

$\square$ külső elismerés igénye $\square$ altruista beállítódás $\square$ teljesítményigény

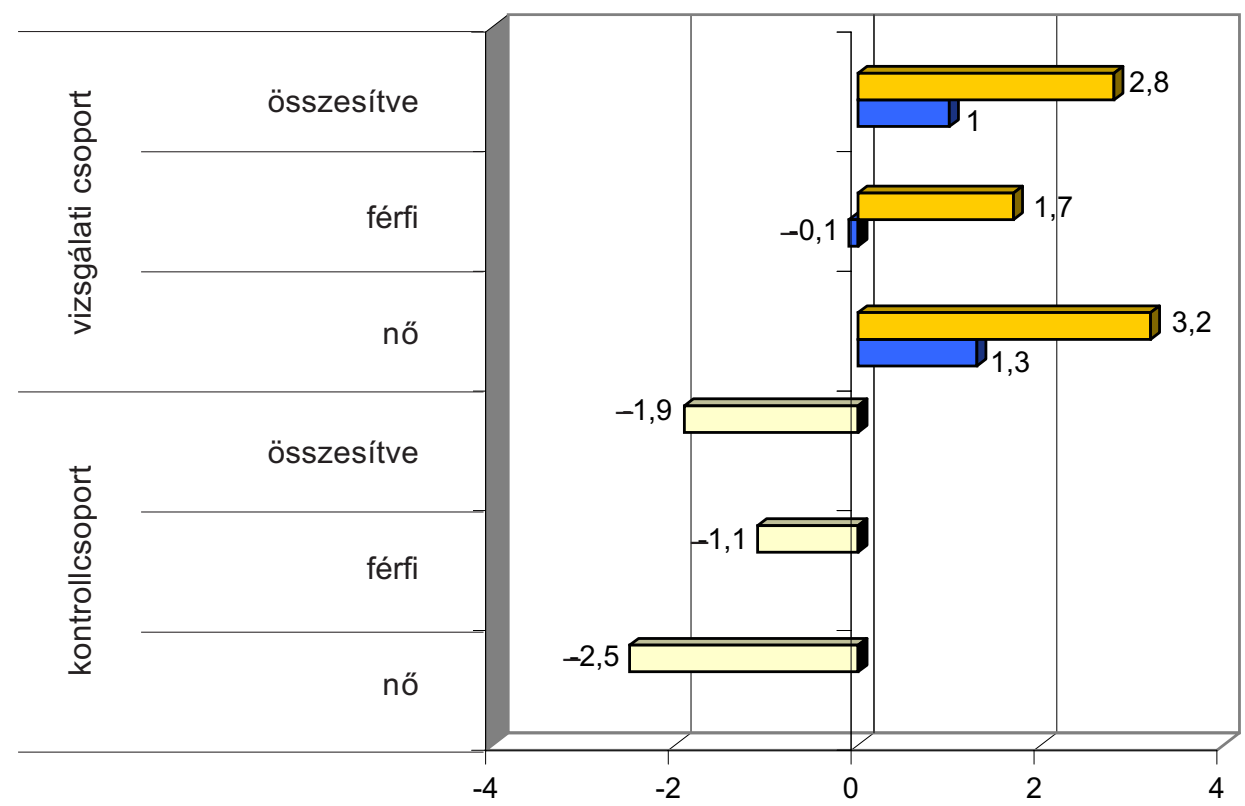

5. ábra. A vizsgálati és a kontrollcsoport Diszfunkcionális Attitúd Skálán nemeknél jelentkező, szignifikáns szintet mutató eltérései 
Az egyik a külsó elismerés igényében jelentkezett $(t=2,45$, sig. $=0,015)$ : mint az ábrán látható, ez inkább jellemzó a nókre, mint a férfiakra. A másik eltérést a fokozott altruizmus területén találtuk, amely szintén a nókre jellemzó attitúd.

A kontrollcsoportnál a nemenkénti összehasonlító statisztikai vizsgálat során csak a teljesítményigény területén mutatkozott szignifikáns eltérés. Az alacsonyabb teljesítményigény elsôsorban a nôknél jelentkezett.

A lineáris regresszió-analízissel azt kívántuk feltárni, hogy a depressziós tünetegyüttest mint függó változót hogyan befolyásolják a Diszfunkcionális Attitúd Skálái mint független változók a minta egészére, valamint külön a vizsgálati és a kontrollcsoportra vonatkoztatva (3. táblázat). A táblázat csak azokat a skálákat tartalmazza, amelyek szignifikáns összefüggést mutattak a depresszió skálán elért eredményekkel.

3. táblázat. A Beck-féle Depresszió Skálán elért eredmények alakulása a diszfunkcionális attitúdök függvényében

\begin{tabular}{|c|c|c|c|c|}
\hline PREDIKTOR & B & BÉTA & T-ÉRTÉK & SZIGNIFIKANCIASZINT \\
\hline \multicolumn{5}{|c|}{ Minta egésze $(\mathrm{n}=681) \mathrm{R}=0,38 ; \mathrm{R}^{2}$-változás $=0,145$} \\
\hline Külsố kontroll attitúd & 0,326 & 0,281 & 7,095 & 0,000 \\
\hline Perfekcionizmus & 0,122 & 0,094 & 2,359 & 0,019 \\
\hline Külső elismerés igénye & 0,122 & 0,092 & 2,213 & 0,027 \\
\hline Szeretetigény & 0,093 & 0,083 & 2,145 & 0,032 \\
\hline Konstans & 6,343 & & 22,046 & 0,000 \\
\hline \multicolumn{5}{|c|}{ Vizsgálati csoport $(\mathrm{n}=170) \mathrm{R}=0,394 ; \mathrm{R}^{2}$-változás = 0,155 } \\
\hline Szeretetigény & 0,193 & 0,219 & 2,732 & 0,007 \\
\hline Külsó kontroll attitûd & 0,209 & 0,201 & 2,562 & 0,011 \\
\hline Konstans & 11,004 & & 20,004 & 0,000 \\
\hline
\end{tabular}

A táblázatból kitúnik, hogy a szubklinikus depressziós tünetegyüttes a minta egészére vonatkoztatva a legszorosabb kapcsolatot a külsó kontroll attitúddel mutatta. Ezt követi a perfekcionizmus, valamint a külsó elismerés igénye és a szeretetigény.

A vizsgálati csoportnál a legszorosabb kapcsolatot a szeretetigény mutatta a szubklinikus depressziós tünetegyüttessel. Ezen kívül csak a külsó kontroll attitúd volt még szoros kapcsolatban a függó változóval.

A kontrollcsoportnál nem találtunk szignifikáns kapcsolatot egyik attitúddel sem.

Lineáris regresszió-analízissel megvizsgáltuk azt is, hogy a rotált faktorok milyen kapcsolatban állnak a diszfunkcionális attitúdökkel.

A legtöbb diszfunkcionális attitúddel a búntudat faktor volt szignifikáns kapcsolatban. Ezek közül a legszorosabb kapcsolat a külsó kontroll attitúddel volt $(B=0,031$, béta $=0,113, t=2,732$, sig. $=0,006)$. Szignifi- 
káns kapcsolatban állt még a búntudat faktor a külsô elismerés igényével $(B=0,03$, béta $=0,096, t=2,209$, sig. $=0,028)$ és a perfekcionizmussal $(B=0,026$, béta $=0,084, t=2,017$, sig. $=0,044)$.

A tiszta depresszió faktor a külsó kontroll attitúddel $(B=0,073$, béta $=$ $0,266, t=6,503$, sig. $<0,001)$ és az altruizmussal $(B=-0,042$, béta $=-0,142$, $\mathrm{t}=-3,513$, sig. $<0,001)$ mutatott szoros összefüggést.

A szomatikus faktor csak a külsó kontroll attitúddel volt szoros kapcsolatban $(B=0,025$, béta $=0,092, t=2,162$, sig. $=0,031)$.

\section{A megküzdési mechanizmusok}

A vizsgálati és a kontrollcsoport tagjainak a Konfliktusmegoldó Kérdőívben elért eredményeinek leíró statisztikája a következó képet mutatta:

Érzelemközpontú megküzdési stratégiák ( $\mathrm{M}=$ átlag, $\mathrm{SD}=$ szórás):

- érzelmi indíttatású cselekvés: vizsgálati csoport $\mathrm{M}=3,6, \mathrm{SD}=2,3$; kontrollcsoport $\mathrm{M}=2,4, \mathrm{SD}=1,9$;

- visszahúzódás: vizsgálati csoport $\mathrm{M}=5,9, \mathrm{SD}=1,9$; kontrollcsoport $\mathrm{M}=4,6, \mathrm{SD}=2,1$;

- érzelmi egyensúly keresése: vizsgálati csoport $\mathrm{M}=3, \mathrm{SD}=1,6$; kontrollcsoport $\mathrm{M}=3, \mathrm{SD}=1,4$.

Problémaközpontú megküzdési stratégiák:

- kognitív átstrukturálás: vizsgálati csoport $\mathrm{M}=6,2, \mathrm{SD}=2,5$; kontrollcsoport $\mathrm{M}=7,1, \mathrm{SD}=2,6$;

- problémaelemzés: vizsgálati csoport $\mathrm{M}=6,7, \mathrm{SD}=1,9$; kontrollcsoport $\mathrm{M}=6,6, \mathrm{SD}=1,9$;

- alkalmazkodás: vizsgálati csoport $\mathrm{M}=5,7, \mathrm{SD}=2,1$; kontrollcsoport $\mathrm{M}=5,1, \mathrm{SD}=2,1$;

Segítségkérés: vizsgálati csoport $\mathrm{M}=5,5, \mathrm{SD}=2,1$; kontrollcsoport $\mathrm{M}=5,4, \mathrm{SD}=2,1$.

A leíró statisztikából kitúnik, hogy a fóiskolai hallgatók mindkét csoportban a problémaközpontú megküzdést részesítik elónyben az érzelemközpontúval szemben.

A 6. ábra a két csoportnak a Családi Szocializációs Kérdőív különbözô skálákon elért átlagai közötti különbséget mutatja be, a vizsgálati csoport szemszögéból.

Ebból kiderül, hogy a legnagyobb különbség a két csoport között a visszahúzódás és az érzelmi indíttatású cselekvés, tehát az érzelemközpontú megküzdés területén volt található. A problémaközpontú megküzdésnél kisebbek a különbségek a két csoport között, és ezek a kognitív átstrukturálás és alkalmazkodás területén voltak. 


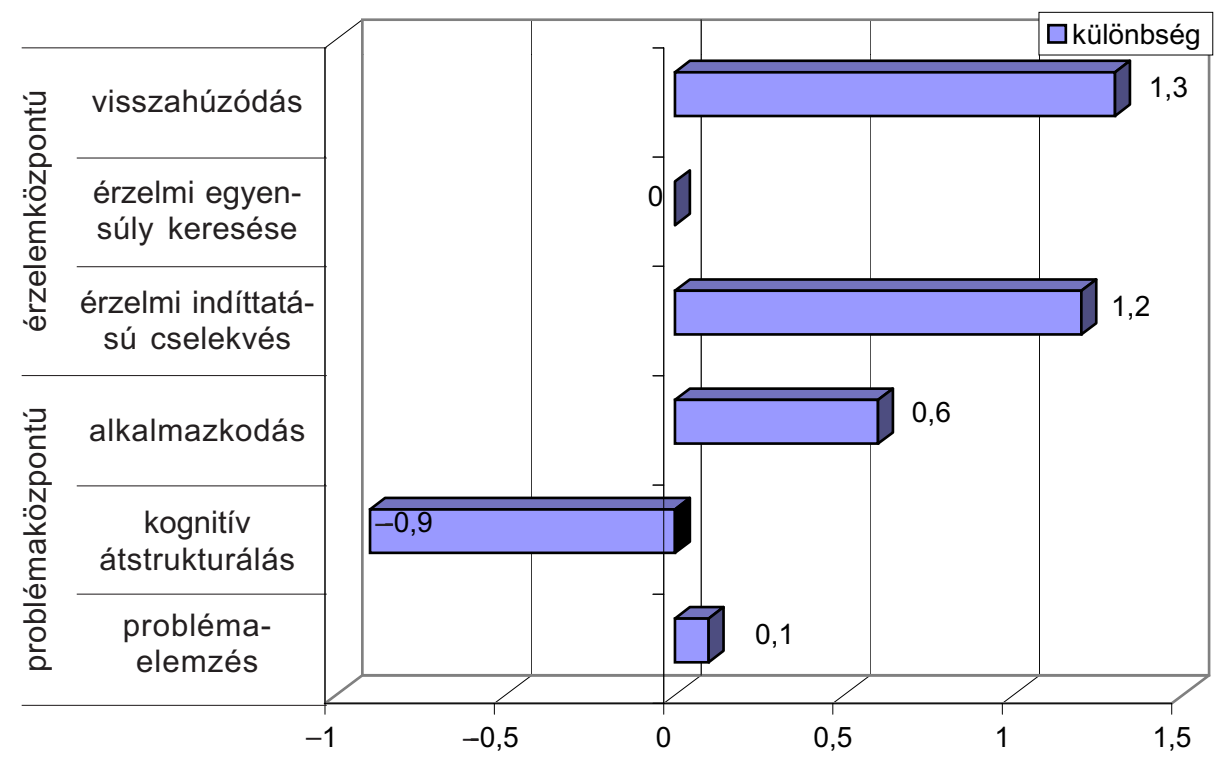

6. ábra. A vizsgálati és a kontrollcsoportnak a Konfliktusmegoldó Kérdôívben elért eredményei, a vizsgálati csoport szemszögéból

Az összehasonlító statisztikai vizsgálatok megerôsítették a fent leírt tendenciákat. A vizsgálatok kimutatták, hogy a problémaközpontú megküzdési stratégiák közül a kognitív átstrukturálás $(t=4,201$, sig. $<0,001)$ és az alkalmazkodás $(t=2,753$, sig. $=0,006)$ területén mutatkozik szignifikáns különbség a vizsgálati és a kontrollcsoport között.

Az érzelemközpontú megküzdési stratégiák területén az érzelmi indíttatású cselekvés $(t=5,557$, sig. $<0,001)$, valamint a visszahúzódás $(t=6,149$, sig. $<0,001)$ területén találtunk szignifikáns különbséget a csoportok között. Ezek a megküzdési formák inkább a vizsgálati csoport tagjaira jellemzőek.

A segítségkérés tekintetében nincs különbség a két csoport között.

A nemek tekintetében külön is megvizsgáltuk a csoportokat, és csak két területen találtunk jelentốs eltérést közöttük. A 7. ábrán a Konfliktuskezelő Kérdốiv azon skáláinak az átlagait láthatjuk, amelyek területén a nemek között szignifikáns eltéréseket találtunk az egyes csoportokon belül.

A vizsgálati csoporton belül a kognitív átstrukturálás területén $(t=2,499$, sig. $=0,013)$ mutatkozott jelentôs eltérés a férfiak javára. A kontrollcsoport tekintetében a visszahúzódásnál találtunk szignifikáns eltérést $(t=4,022$, sig.<0,001), a nóket inkább jellemzi ez a fajta megküzdési mód. 


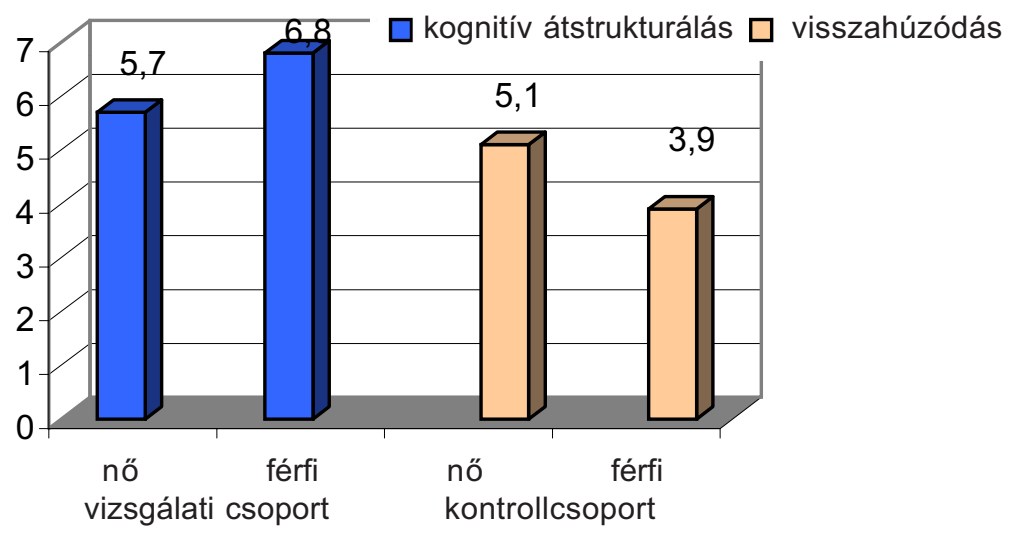

7. ábra. A vizsgálati és a kontrollcsoportnak a Konfliktusmegoldó Kérdőívben nemeknél jelentkező, szignifikáns szintet mutató skálák átlagai

A lineáris regresszió-analízissel azt vizsgáltuk, hogy a depressziós tünetegyüttest mint függó változót hogyan befolyásolják a Konfliktuskezelő Kérdốiv skálái mint független változók a minta egészére nézve, valamint külön a vizsgálati és a kontrollcsoport vonatkozásában is (4. táblázat). A táblázat csak azokat a skálákat tartalmazza, amelyek szignifikáns összefüggést mutattak a depresszió skálán elért eredményekkel.

4. táblázat. A Beck-féle Depresszió Skálán elért eredmények alakulása a megküzdési stratégiák függvényében

\begin{tabular}{|c|c|c|c|c|}
\hline PREDIKTOR & B & BÉTA & T-ÉRTÉK & SZIGNIFIKANCIASZINT \\
\hline \multicolumn{5}{|c|}{ Minta egésze $(n=681) R=0,439 ; R^{2}$-változás $=0,192$} \\
\hline Visszahúzódás & 0,519 & 0,25 & 6,305 & 0,000 \\
\hline Érzelmi indíttatású cselekvés & 0,499 & 0,256 & 6,741 & 0,000 \\
\hline Kognitív átstrukturálás & $-0,354$ & $-0,209$ & $-5,51$ & 0,000 \\
\hline Segítségkérés & $-0,244$ & $-0,116$ & $-2,857$ & 0,004 \\
\hline Alkalmazkodás & 0,199 & 0,096 & 2,535 & 0,012 \\
\hline Konstans & 4,186 & & 5,543 & 0,000 \\
\hline \multicolumn{5}{|c|}{ Vizsgálati csoport $(\mathrm{n}=170) \mathrm{R}=0,359 ; \mathrm{R}^{2}$-változás = 0,156 } \\
\hline Érzelmi indíttatású cselekvés & 0,438 & 0,28 & 3,509 & 0,001 \\
\hline Visszahúzódás & 0,419 & 0,218 & 2,637 & 0,009 \\
\hline Konstans & 10,582 & & 7,062 & 0,000 \\
\hline \multicolumn{5}{|c|}{ Kontrollcsoport $(\mathrm{n}=204) \mathrm{R}=0,397 ; \mathrm{R}^{2}$-változás = 0,158 } \\
\hline Érzelmi indíttatású cselekvés & 0,137 & 0,239 & 3,158 & 0,002 \\
\hline Érzelmi egyensúly keresése & 0,148 & 0,192 & 2,642 & 0,009 \\
\hline Kognitív átstrukturálás & $-0,08$ & $-0,189$ & $-2,573$ & 0,011 \\
\hline Konstans & 1,264 & & 3,681 & 0,000 \\
\hline
\end{tabular}


Az eredmények azt mutatják, hogy a szubklinikus depressziós tünetegyüttes a minta egészére nézve, a legszorosabb kapcsolatban az érzelemközpontú megküzdési módok elônyben részesítésével volt, konkrétan az érzelmi indíttatású cselekvéssel és a visszahúzódással. Az érzelmi indíttatású cselekvéssel való kapcsolat megjelent a vizsgálati csoportnál és a kontrollcsoportnál is. A visszahúzódással való kapcsolatot csak a vizsgálati csoportnál tudtuk megerősíteni, helyette a kontrollcsoportnál az érzelmi egyensúly keresésére való törekvést találtuk.

A problémaközpontú megküzdési stratégiák közül a depressziós tünetegyüttes a kognitív átstrukturálás hiányával, valamint a külsó alkalmazkodással mutatott szoros kapcsolatot. A vizsgálati csoportnál nem tudtuk megerősíteni ezt az összefüggést, a kontrollcsoportnál is csak a kognitív átstrukturálás hiányánál.

A minta egészére nézve szoros kapcsolatot mutatott még a depressziós tünetegyüttes a segítségkérés hiányával, de ezt külön sem a vizsgálati, sem a kontrollcsoportoknál nem tudtuk kimutatni

Lineáris regresszió-analízissel megvizsgáltuk azt is, hogy a rotált faktorok milyen kapcsolatot mutatnak a megküzdési stratégiákkal. A tiszta depresszió faktor a legszorosabb kapcsolatot az érzelemközpontú megküzdési stratégiákkal mutatta, ezen belül is az érzelmi indíttatású cselekvéssel $(B=0,089$, béta $=0,193, t=4,815$, sig. $<0,001)$, valamint a visszahúzódással $(\mathrm{B}=0,097$, béta $=0,199, \mathrm{t}=4,75$, sig. $<0,001)$. A problémaközpontú megküzdési stratégiák közül csak a kognitív átstrukturálás hiányával volt szoros kapcsolatban $(B=-0,052$, béta $=-0,13, t=-3,241$, sig. $=0,001)$. Szignifikáns összefüggést mutatott még a segítségkérés hiányával $(B=-0,059$, béta $=-0,118, t=-2,77$, sig. $=0,006)$.

A búntudat faktor szintén négy megküzdési stratégiával mutatott szignifikáns összefüggést. Az érzelemközpontúak közül ez is az érzelmi indíttatású cselekvéssel $(B=0,083$, béta $=0,18, t=4,459$, sig. $<0,001)$ és a visszahúzódással $(B=0,064$, béta $=0,132, t=3,121$, sig. $=0,002)$ volt kapcsolatban. A problémaközpontúak közül a kognitív átstrukturálás hiányával $(\mathrm{B}=-0,053$, béta $=-0,133, \mathrm{t}=3,121$, sig. $=0,002)$, valamint az alkalmazkodással $(B=0,049$, béta $=0,1, t=2,486$, sig. $=0,013)$ mutatott szoros kapcsolatot.

A szomatikus faktor csak a kognitív átstrukturálás hiányával $(B=-0,038$, béta $=-0,095, t=-2,292$, sig. $=0,022)$ és a visszahúzódással $(B=0,044$, béta $=0,091, \mathrm{t}=2,093$, sig. $=0,037)$ mutatott szignifikáns összefüggést. 


\section{Az attribúciós stílus}

A vizsgálati és a kontrollcsoport tagjainak az Attribúciós Stílus Kérdőívben elért eredményeinek leíró statisztikája a következóképpen alakult:

Teljesítménydeficit esetén:

- külsó vagy belsó: vizsgálati csoport $\mathrm{M}=5, \mathrm{SD}=1,1$; kontrollcsoport $\mathrm{M}=4,9, \mathrm{SD}=1,2$;

- instabil vagy stabil: vizsgálati csoport $\mathrm{M}=4,8, \mathrm{SD}=1,4$; kontrollcsoport: $\mathrm{M}=4,1, \mathrm{SD}=1,6$;

- specifikus vagy globális: vizsgálati csoport $\mathrm{M}=4,2, \mathrm{SD}=1,7$; kontrollcsoport $\mathrm{M}=2,9, \mathrm{SD}=1,7$.

Veszteség esetén:

- külsô vagy belsó: vizsgálati csoport $\mathrm{M}=3,9, \mathrm{SD}=1,3$; kontrollcsoport $\mathrm{M}=3,9, \mathrm{SD}=1,2$;

- instabil vagy stabil: vizsgálati csoport $\mathrm{M}=4, \mathrm{SD}=1,5$; kontrollcsoport $\mathrm{M}=3,6, \mathrm{SD}=1,5$;

- specifikus vagy globális: vizsgálati csoport $\mathrm{M}=3,9, \mathrm{SD}=1,6$; kontrollcsoport $\mathrm{M}=3,2, \mathrm{SD}=1,6$.

A 8. ábra a két csoportnak az Attribúciós Stílus Kérdôív különböző skálákon elért átlagai közötti különbséget mutatja be, a vizsgálati csoport szemszögéból.

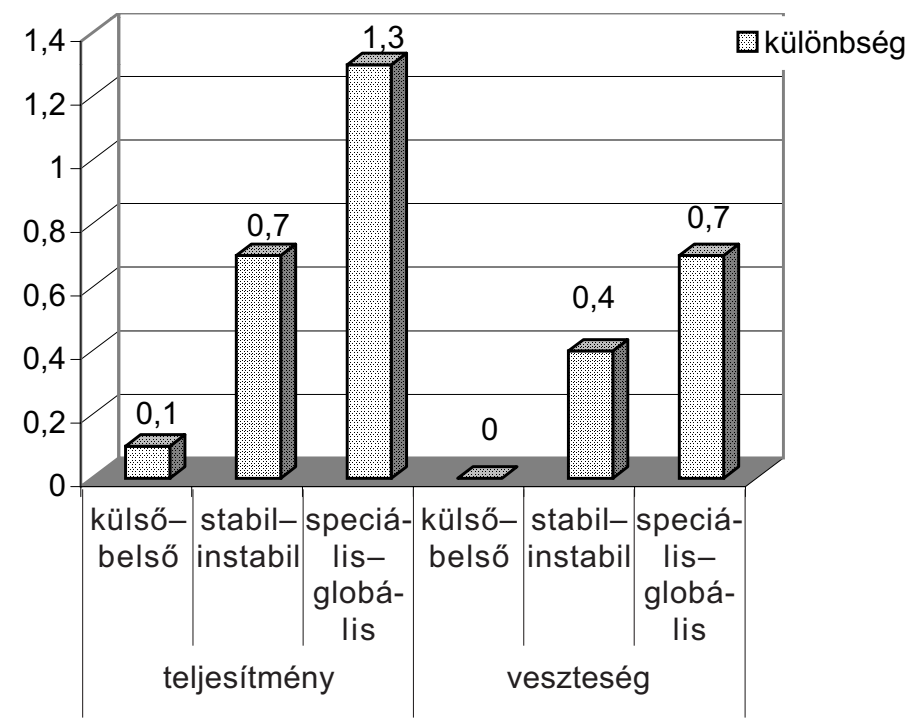

8. ábra. A vizsgálati és a kontrollcsoport Attribúciós Stílus Kérdőív különböző skáláin elért átlagainak különbségei, a vizsgálati csoport szemszögéból 
Az ábrán látható, hogy a teljesítménydeficitet inkább tulajdonítják belsô oknak és stabilnak, mint a veszteséget. A vizsgálati és a kontrollcsoport között jelentôs, szignifikáns eltérés mutatkozott a stabilitás és a globalitás megítélése területén. A vizsgálati csoport tagjai stabilabbnak tulajdonítják az okokat (mindig jelen lesz) mind a teljesítmény ( $t=4,018$, sig.<0,001), mind a veszteség $(t=2,611$, sig. $=0,009)$ területén, mint a kontrollcsoport tagjai. Ugyanez a helyzet a globalitás megítélésében is (teljesítmény: $\mathrm{t}=7,193$, sig.<0,001; veszteség: $\mathrm{t}=4,256$, sig.<0,001).

A csoportokon belül, nemenként elvégzett összehasonlító statisztikai vizsgálat nem mutatott jelentôs különbséget a nók és a férfiak attribúciós stílusa között.

A lineáris regresszió-analízissel azt akartuk feltárni, hogy a depressziós tünetegyüttest mint függó változót hogyan befolyásolják az Attribúciós Stílus Kérdôív skálái mint független változók a minta egészére nézve, valamint külön a vizsgálati és a kontrollcsoport vonatkozásában is (5. táblázat). A táblázat csak azokat a skálákat tartalmazza, amelyek szignifikáns összefüggést mutattak a depresszió skálán elért eredményekkel.

Az eredmények azt mutatják, hogy a szubklinikus depressziós tünetegyüttes a minta egészére nézve a saját teljesítménydeficit megítélésekor (nem sikerült egy fontos vizsga) a legszorosabb kapcsolatot a specifikus vagy globális, valamint instabil vagy stabil attribúciós dimenzióval mutatta. Veszteség megítélésekor (szakítás egy közeli baráttal, barátnóvel) szintén a specifikus vagy globális attribúcióval találtunk összefüggést. A vizsgálati csoportnál nem tudtuk ezeket megerôsíteni, hanem teljesítménydeficit esetében a külsó-belsó attribúció és a depressziós tünetegyüt-

5. táblázat. A Beck-féle Depresszió Skálán elért eredmények alakulása az attribúciós stílus függvényében

\begin{tabular}{|c|c|c|c|c|}
\hline PREDIKTOR & B & BÉTA & T-ÉRTÉK & SZIGNIFIKANCIASZINT \\
\hline \multicolumn{5}{|c|}{ Minta egésze $(\mathrm{n}=681) \mathrm{R}=0,352 ; \mathrm{R}^{2}$-változás $=0,124$} \\
\hline $\begin{array}{l}\text { Teljesítmény: specifikus } \\
\text { vagy globális }\end{array}$ & 0,608 & 0,257 & 6,498 & 0,000 \\
\hline $\begin{array}{l}\text { Teljesítmény: instabil } \\
\text { vagy stabil }\end{array}$ & 0,32 & 0,115 & 2,992 & 0,003 \\
\hline $\begin{array}{l}\text { Veszteség: specifikus } \\
\text { vagy globális }\end{array}$ & 0,213 & 0,081 & 1,975 & 0,049 \\
\hline Konstans & 1,108 & & 1,203 & 0,230 \\
\hline \multicolumn{5}{|c|}{ Vizsgálati csoport $(\mathrm{n}=170) \mathrm{R}=0,306 ; \mathrm{R}^{2}$-változás = 0,093 } \\
\hline Teljesítmény: külsó vagy belsó & 0,608 & 0,191 & 2,525 & 0,013 \\
\hline Konstans & 4,313 & & 2,502 & 0,013 \\
\hline
\end{tabular}


tes kapcsolatát tudtuk kimutatni. A kontrollcsoport esetében nem találtunk szignifikáns kapcsolatot a vizsgált tényezók között.

Lineáris regresszió-analízissel megvizsgáltuk azt is, hogy a rotált faktorok milyen kapcsolatot mutatnak az attribúciós stílussal. A vizsgálat során csak a teljesítmény megítélésével kapcsolatban találtunk szignifikáns összefüggéseket a rotált faktorokkal. A tiszta depresszió faktor legszorosabb kapcsolatban a globalitás $(B=0,077$, béta $=0,138, t=3,331$, sig. $=0,001)$, valamint a stabilitás $(B=0,06$, béta $=0,093, t=2,314$, sig. $=$ $0,021)$ megítélésével volt. A búntudat faktor a belsó okoknak való tulajdonítással $(B=0,105$, béta $=0,126, t=3,323$, sig. $=0,001)$ és a globalitással $(B=0,7$, béta $=125, t=3,054$, sig. $=0,002)$ mutatott szoros összefüggést. A szomatikus faktor csak a globalitás megítélésével $(B=0,103$, béta $=0,185, \mathrm{t}=4,488$, sig. $<0,001)$ volt szoros kapcsolatban.

\section{A háttértényezók vizsgálata}

A háttértényezók felkutatásánál a vizsgálat során felhasznált kérdőívek minden olyan skáláját figyelembe vettük, amelyeknél az összehasonlító statisztikai vizsgálatok során szignifikáns eltérés mutatkozott a két csoport között. A vizsgálat során csak a rotált faktorokat, valamint az általános gyakorlatnak megfelelóen a 0,4-nél nem kisebb faktorsúlyokat vettük figyelembe a háttértényezôk differenciálásánál (6. táblázat).

6. táblázat. A vizsgálat során a két csoport között szignifikáns különbséget jelző skálák strukturálódása a másodrendú faktoranalízis alapján (l>0.40)

\begin{tabular}{|c|c|c|c|c|}
\hline & \multicolumn{4}{|c|}{ Faktorok } \\
\hline & 1 & 2 & 3 & 4 \\
\hline Külsó elismerés igénye & 693 & & & \\
\hline Szeretettség igénye & ,560 & & & \\
\hline Teljesítményigény & 710 & & & \\
\hline Perfekcionizmus & 622 & & & \\
\hline Külsô kontroll-autonómia & 621 & & & \\
\hline Kognitív átstrukturálás & & & & ,883 \\
\hline Érzelmi indíttatású cselekvés & & & 717 & \\
\hline Visszahúzódás & & &, 575 & \\
\hline Alkalmazkodás & & & 692 & \\
\hline Teljesítmény: instabil vagy stabil attribúció & & ,491 & & \\
\hline Teljesítmény: specifikus vagy globális attribúció & & ,764 & & \\
\hline Veszteség: specifikus vagy globális attribúció & & ,784 & & \\
\hline
\end{tabular}


A faktoranalízis eredménye a vizsgált változóknak megfeleló strukturálódást mutat. A vizsgált változók négy faktorba rendeződtek és a teljes varianciának a 52,2\%-át magyarázták.

Az elsố faktor (sajátérték: 2,551), mely a teljes variancia 21,2\%-át magyarázta, a vizsgált diszfunkcionális attitúdöket jelöli.

A második faktor (sajátérték: 1,5), mely a teljes variancia 12,5\%-át magyarázta, a pesszimista attribúciós stílust írja le.

A harmadik faktor (sajátérték: 1,194), mely a teljes variancia 9,91\%-át magyarázta, az érzelmi indíttatású cselekvést jelöli. Érdekes, hogy ide került az alkalmazkodás is, mint problémaközpontú megküzdési stratégia.

A negyedik faktor (sajátérték: 1,03), mely a teljes variancia 8,6\%-át magyarázta, a kognitív átstrukturálást írja le.

A rotált faktorokra elvégeztük a lineáris regresszió-analízist is, amely minden faktor esetében szignifikáns összefüggést $($ sig.<0,001) mutatott a depressziós tünetegyüttessel.

\section{ÖSSZEFOGLALÁS}

A kutatás eredményei azt mutatják, hogy a depressziós tünetegyüttes elófordulása a fóiskolai populációban nem tér el jelentôsen az irodalomban jelzett arányoktól, bár kissé magasabb értékeket mutat. Ez a növekedés része lehet a Kopp és mtsai (1997) vizsgálatai által jelzett progresszív tendenciának, de adódhat a méróeszközök különbözőségéból is (Kopp és mtsai a Beck-féle Depresszió Kérdőív 9 tételes változatát használták kutatásaik során). Comer (2003) összefoglalása szerint a fejlett ipari országokban a nók kétszer olyan gyakran élnek át súlyos unipoláris depressziót, mint a férfiak. Ezt az arányt tükrözik a vizsgálat eredményei is, szubklinikus mintán. A tünetek súlyosság szerinti megítélése azt mutatta, hogy legerósebben a bûntudat-szindróma (búntudat, félelem a büntetéstôl, határozatlanság) jelentkezett a vizsgálati személyeknél, amelyet a fáradtság szindróma követett (fáradtság, munkaképtelenség, étvágytalanság). A tiszta depresszió tünetei közül csak az elégedetlenség és reménytelenség jelentkezett erósebben.

Kutatásunk eredményei nagyrészt igazolták első hipotézisünket, amely szerint a szubklinikus depressziós tünetegyüttessel jellemezhetô személyekre a szeretet- és elismerésigény, teljesítményigény, valamint perfekcionizmus fokozottan jellemzô. A vizsgálat eredményei csak részben erôsítik meg Kopp és mtsai (1997) által ezen a területen feltárt összefüggéseket. A minta egészére nézve megerôsítést nyert a fokozott szeretetigény, 
külsó elismerésigény és perfekcionizmus, de nem jelentkezett a fokozott teljesítményigény. A szubklinikus depressziós tünetegyüttessel a legszorosabb kapcsolatot a külsó kontroll attitúd esetében találtunk, valamint ezen a területen jelentkezett a vizsgálati és a kontrollcsoport között a legnagyobb különbség is. Kopp és Skrabski (1995) úgy találták, hogy a 16 és 20 év közötti, szorongó, neurotikus tünetekre panaszkodó fiatalokra szintén jellemzó a külső kontrollosság. Fiske és Taylor (1984) szerint a személy önértékelése és énképe meghatározásának a szempontjából nagyon fontos az, hogy a személy mennyire tartja magát hatékonynak egy szituációban, mennyire érzi, hogy befolyásolni, kontrollálni tudja azt. A kontroll észlelése tehát fontos szempontja annak, hogy a személy hogyan viselkedik egy adott helyzetben. A vizsgálati csoport tagjait tehát a külsókontrollosság jellemezte. A külsó kontroll attitúddel jellemezhetố személy úgy érzi, hogy nem saját maga irányítja sorsát, a helyzetek csak megtörténnek vele (Kopp 2001). Az így keletkezó passzív, tehetetlenségi állapot Seligman (1992) szerint kialakíthatja a személynél azt az implicit hiedelmet, hogy nincs befolyása élete alakítására, bármit is tesz, az nincs hatással az események alakulására. Ezért passzívvá válhat, motivációja csökkenhet, hajlamossá válhat a depresszióra. Ennek az ellentéte az autonómia, az önállóságra való beállítódás, ami vizsgálatunkban inkább volt jellemzó a kontrollcsoportra.

Jelentốs, szignifikáns eltérés mutatkozott még a teljesítményigény és a perfekcionizmus területén is a csoportok között. A kutatás eredményei azt mutatják, hogy a teljesítményigény nem igazán volt jellemző egyik csoport esetében sem, de a vizsgálati csoport tagjai magasabb pontszámot értek el ezeken a skálákon. A perfekcionista attitúddel jellemezhetó személy mindent minden részletében tökéletesen szeretne megoldani. Önmagával és környezetével is elégedetlen, ha ez nem sikerül (Kopp 2001). A szeretetigény, valamint a külsó elismerés igénye szintén jellemzóbb volt a vizsgálati csoportot tagjaira. A fentiekból sikerült megerôsíteni perfekcionizmus, elismerés- és szeretetigény szignifikáns kapcsolatát a depressziós tünetegyüttessel, azonban fokozott teljesítményigényre utaló jeleket nem találtunk. Úgy látszik, hogy nem a tényleges számszerú értékek döntóek ebben az esetben, hanem a személy szubjektív értékelése. Egy alacsony szintú teljesítményigény is vezethet fokozott perfekcionizmus mellett depresszív hangulat kialakulásához, ha a személy úgy érzi, hogy az elvárásokhoz képest kevesebbet teljesített.

A vizsgálati csoportban a nemek között a nókre szignifikánsan jobban jellemzőnek találtuk a fokozott teljesítményigényt és az altruista attitúdöt. Kopp (2001) szerint, ha az altruista attitúd nem talál viszonzásra, akkor csalódást, kiábrándulást eredményezhet, így válhat az enyhe de- 
pressziós tünetegyüttes egyik háttértényezójévé. Ugyanez érvényes lehet a ki nem elégített elismerésigény esetében is.

A megküzdési stratégiákat vizsgálva megállapíthatjuk, hogy a depressziós tünetegyüttessel a legszorosabb összefüggést az érzelemközpontú megküzdési módok mutatták, elsősorban az érzelmi indíttatású cselekvés és a visszahúzódás, valamint a kognitív átstrukturálás hiánya. Ezek az eredmények megerósítik a második hipotézisünket, amely szerint a depressziós tünetegyüttessel jellemezhetô személyekre inkább az érzelemközpontú megküzdési módok jellemzók, ezen belül is hajlamosak a visszahúzódásra.

Ha a megküzdési módok használatának a preferenciáját nézzük, akkor kiderül, hogy a főiskolai hallgatók mindkét csoportban a problémaközpontú megküzdést részesítik előnyben az érzelemközpontúval szemben. A depressziós tünetegyüttessel jellemezhetô személyek is többet használják a problémaközpontú megküzdést, mint az érzelemközpontút. A problémaközpontú megküzdési módok közül a kognitív átstrukturálás azt jelenti, hogy nehéz élethelyzetekból a helyzet újraértelmezése által más emberként, a személyiségfejlődés magasabb szintjén kerül ki a személy (Kopp 2001). A kognitív átstrukturálást mint megküzdési módot kevésbé használják a vizsgálati csoport tagjai. Az alkalmazkodás mint megküzdési mód azt jelenti, hogy a személy elfogadja az adott helyzetet, anélkül, hogy magát okolná annak kialakulásáért. A vizsgálati csoportra inkább jellemzó ez a megküzdési mód. Ez a külsó kontrollosságukban gyökerezhet, abban a hiedelmükben, hogy nincs lehetőségük a sorsuk irányítására, hanem passzív rezignációval elfogadják a kialakult helyzetet. A kognitív átstrukturálás területén a vizsgálati csoport tagjainál a nemek között is szignifikáns különbséget találtunk. A nôkre kevésbé jellemzó ez a megküzdési mód, mint a férfiakra. A kontrollcsoporton belül nem tudtuk kimutatni ezt a tendenciát.

Az irodalmi adatokkal egyezóen egyértelmúen beigazolódott harmadik hipotézisünk, amely szerint a depressziós tünetegyüttessel pesszimista attribúciós stílus jár együtt. A minta egészére vonatkoztatva a teljesítménydeficit és veszteség megítélésekor is globálisnak ítélik meg az okot, valamint teljesítménydeficit esetében stabilnak is. Vizsgálatunk eredménye azt mutatja, hogy a vizsgálati csoport tagjai a kontrollvesztést belsó okokra vezetik vissza, stabilabbnak, valamint globálisabbnak vélik az okokat mind a teljesítmény, mind a veszteség területén, mint a kontrollcsoport tagjai, és ez független a nemi hovatartozásuktól. A pesszimista attribúciós stílusú emberek úgy érzik, hogy nem befolyásolhatják életük alakulását. Abramson és mtsai (1989) szerint a pesszimista attribúciós stílus önmagában nem elegendó oka a depressziónak, akkor válik fontossá, 
ha a személy erốs vagy gyakori negatív életeseményekkel találja szemben magát. Szerintük a depresszió kialakulása szempontjából az a fontosabb, hogy valaki mennyire hiszi befolyásolhatónak a saját életét, és nem az, hogyan értelmezi a kellemetlen eseményeket. A hit, hogy meg tud küzdeni a negatív életeseményekkel, növeli a depresszióval szembeni ellenállását. A már említett külsó-kontrollosság azonban pont ennek a kialakulását nehezíti meg a depressziós tünetegyüttessel jellemezhető személyeknél. Kulcsár (2002) szerint a sikeres megküzdési stratégiák optimizmussal, valamint pozitív gondolkodással járnak együtt. Peterson és mtsai (1982) longitudinális vizsgálatai azt mutatják, hogy a korán kialakuló optimista attribúciós stílus a lelki egészségen túl a testi egészséget is megalapozhatja.

Kutatásunk eredményei rámutatnak arra a tényre, hogy a szubklinikus depressziós tünetegyüttes, a diszfunkcionális attitúdök, a maladaptív megküzdési stratégiák, valamint a pesszimista attribúciós stílus jelen vannak, és kifejtik romboló hatásukat a nem klinikai populációhoz tartozó fóiskolai hallgatók körében is.

Pikó (2002) szerint a depresszió a mai, modern társadalom kortünete. A társadalom a teljesítményt ismeri el, ebben az értelemben az önmegvalósítás is teljesítménykategória. A fogyasztói társadalmak latensen irányítják tagjaikat, csak az elérendő célokat, értékeket közlik velük, a megvalósításukhoz vezetô utakat az egyén szabad választására bízzák. A választás felelóssége az egyéné, a rossz választásokért, kudarcokért is ó a felelôs. A teljesítménydeficit gyakran kelt szorongást és búntudatot az egyénben, így a depresszió - Pikó értelmezésében - nem más, mint az önmegvalósítás deficitje. A másik fontos sajátossága ezeknek a társadalmaknak a tagjaik énközpontúsága, az énnek a túlhangsúlyozása. Ez nárcisztikus személyiségtorzulásra, interperszonális zavarokra, elidegenedésre és a társas kapcsolatok felszínességére hajlamosít. A depresszió ebben az értelemben az egóba való belesüppedést jelenti, amely megakadályozza a másik felé fordulást. Egy harmadik sajátossága ezeknek a társadalmaknak, hogy a hétköznapi élet során megsokszorozódnak bennük azok a konfliktusok, amelyek alkalmazkodást igényelnének tagjaiktól. Konfliktuskezelési stratégiákból azonban a társadalom azokat preferálja, amelyek a kellemetlen eseményeket minél gyorsabban, minél kevesebb ráfordítással iktatják ki. Többek között ez állhat a dohányzás, az alkohol- és drogfogyasztás, a gyógyszerfüggőség magas szintjének a hátterében is.

Felmerül a kérdés, hogy milyen preventív lehetôségekkel rendelkeznek az egyetemek és fóiskolák ezeknek a hatásoknak a kivédésére, minimalizálására. Kopp és Skrabski (2001) felhívják a figyelmet az iskola szerepé- 
re az egészségmegórzó magatartás kialakításában, az együttmúködési és konfliktusmegoldó készségek fejlesztése területén.

A mentálhigiénés megelőzési programok bevezetése és a tanácsadási rendszer kialakítása mellett fontos lenne a képzés folyamatába beépíteni egy olyan, kötelezó tantárgyblokkot, amelynek célja az egyetemi, fóiskolai hallgató személyiségének fejlesztése, az adekvát megküzdési módok kialakítása lehetne.

\section{Irodalom}

Abramson, L. Y., Metalsky, G. I., Alloy, L. B. (1989): Hopelessness depression. A theorybased subtype of depression. Psychological Review, 96: 358-372.

Atkinson, R. L., Atkinson, C. R., Smith, E. E., Bem, D. J. (1995): Pszichológia. Osiris, Budapest.

Beck, A. T., Beck, R. W. (1972): Screening depressed patients in family practice. A rapid technique. Postgrad. Med., 52: 81-85.

Beck, A. T., Rush, A. J., Shaw, B. F., Emery, G. (2001): A depresszió kognitív terápiája. Animula, Budapest.

Burns, D. D. (1980): Feeling Good. The Mood Therapy. Signet and Mentor, New York.

Comer, R. J. (2003). A lélek betegségei. Osiris, Budapest.

Csabai M., Molnár P. (1999): Egészség, betegség, gyógyítás. Springer, Budapest.

Csorba J., Dinya E., Párt S., Solymos J. (1994): Életesemény kutatás és serdülókor. A középiskolás életesemény kérdôív bemutatása. Magyar Pszichológiai Szemle, 50 (1): 67-83.

Csorba J., Farkas V., Mihádák K. (1996): Diszfunkcionális személyiségi attitűdök és depresszió migrén típusú fejfájásban szenvedô serdülóknél. Ideggyógyászati Szemle, 49 (3-4): 89-95.

Fiske, S. T., Taylor, S. E. (1984): Social Cognition. Random House, New York.

Kopp M. (1994): Orvosi pszichológia. SOTE Magatartástudományi Intézet, Budapest.

Kopp M. (2001): Magatartástudományi ember-környezeti rendszerelméleti modell. In: Buda B., Kopp M., Nagy E. (szerk.): Magatartástudományok. Medicina, Budapest, 23-46.

Kopp M., Csoboth Cs., Purebl Gy. (1999): Fiatal nók egészségi állapota. In Pongrácz T., Tóth I. Gy. (szerk.): Szerepváltozások. TÁRKI, Budapest, 239-259.

Kopp M., Skrabski Á. (1995): Alkalmazott magatartástudomány. Corvinus Kiadó, Budapest.

Kopp M., Skrabski Á. (2001): Magatartás és család. Új Bioetikai Szemle, 7 (4): 1-25.

Kopp M., Szedmák S., Lóke J., Skrabski Á. (1997): A depressziós tünetegyüttes gyakorisága és egészségügyi jelentôsége a mai magyar lakosság körében. Lege Artis Medicinae, 7 (3): 136-144.

Kulcsár Zs. (2002): Egészségpszichológia. ELTE Eötvös Kiadó, Budapest.

Lazarus, R. S. (1990): Stress, coping and illness. In Friedman, H. S. (ed.): Personality and Disease. Wiley, New York, 84-86.

Lazarus, R. S., Folkman, S. (1986): Coping and adaptation. In Gentry, W. D. (ed.): The Handbook of Behavioral Medicine. Guilford, New York.

Lazarus, R. S., Launier, R. (1978): Stress related transactions between person and environment. In Pervin, L., Lewis, M. (eds): Internal and External Determinants of Behavior. Plenum Press, New York. 
Metalsky, G. I., Halberstadt, L. J., Abramson, L. Y. (1987): Vulnerability to depressive mood reactions. Journal of Personality and Social Psychology, 52: 386-393.

Molnár G., Molnár I. (1999): A Beck- és Zung-féle depresszió önértékelő tesztek faktoranalízise. Pszichoterápia, 8: 165-173.

Peterson, C., Semmel A., von Baeyer, C., Abramson, L., Metalsky, G., Seligman, M. (1982): The attributional style questionnaire. Cognitive Therapy and Research, 6: 287-299.

Pikó B. (2002): A depresszió társadalom-lélektana: kórtünet vagy kortünet? Valóság, 45 (7): 53-62.

Rózsa S., Szádóczky E., Füredi J. (2001): A Beck Depresszió Kérdôív rövidített változatának jellemzói hazai mintán. Psychiatria Hungarica, 16: 384-402.

Seligman, M. E. P. (1992): Wednesday's children. Psychol. Today, 25 (19): 61-67.

Szádóczky E. (2001a): Epidemiológia. In Szádóczky E., Rihmer Z. (szerk.): Hangulatzavarok. Medicina Könyvkiadó, Budapest, 150-168.

Szádóczky E. (lekt.) (2001b): Depresszió, szorongás pontozó skálák. EGIS, Budapest.

Volk, R. J., Pace, T. M., Parchman, M. L. (1993): Screening for depression in primary care patients: dimensionality of short Beck Depression Inventory. Psychol. Assess, 5: 173-181.

Vredenburg, K., Kramels, L., Flett, G. L. (1985): Reexamining the Beck Depression Inventory: the long and short of it. Psychol. Reports, 56: 767-778.

Weismann, A. N., Beck, A. T. (1979): The Dysfunctional Attitude Scale. Thesis, University of Pennsylvania.

Köszönetnyilvánítás. Köszönettel tartozom témavezetőmnek, Dr. Bugán Antalnak, aki munkám során elméleti és gyakorlati tanácsokkal, javaslatokkal, ószinte kritikával segített. Külön köszönetet szeretnék mondani a Nyíregyházi Főiskola, Pszichológia Tanszék oktatóinak a munkámhoz nyújtott segítségükért és türelmükért, valamint köszönet illeti a Nyíregyházi Fóiskola hallgatóit is, akik vállalták a kérdóívek kitöltését.

\section{MARGITICS, FERENC}

\section{INTERRELATIONS BETWEEN SUBCLINICAL DEPRESSIVE SYNDROME AND DYSFUNCTIONAL ATTITUDES, COPING STRATEGIES AND ATTRIBUTIONAL STYLE AT COLLEGE STUDENTS}

In the course of our research we intended to survey the presence of dysfunctional attitudes related to subclinical depressive symptoms, the preferred coping strategies and attributional style at students who do not belong to any clinical population, and whose socialization may be described as successful. 681 participants were involved in the research, 465 of them were women, and 216 men. Students who were put into the fourth quadrant of Beck's Depression Scale by their scores belonged to the research group (170 individuals, 128 women, 42 men). The control group (204 individuals, 118 women and 86 men) consisted of students who were in the first quadrant of Beck's scale. The result findings show that the occurrence of the depressive syndrome at college students is not any significantly different from proportions described in the related literature, although slightly higher. The members of the research group are primarily characterized by external control attitude of all the dysfunc- 
tional attitudes. A look at the coping strategies show that people with depressive syndrome use problem-centred coping strategies. They, however, use these strategies (especially cognitive re-structuring and adaptation) to a much lesser extent than the members of the control group. In terms of cognitive re-structuring, there has been a significant difference between the two genders. Women tend to use this strategy much less frequently than men do. No similar tendency has been observed in the control group. Out of the emotional coping strategies, retreat has been found to be the most common at the individuals with subclinical syndrome. At students with depressive syndrome, pessimistic attributional style has been found characteristic. The results show, that the members of the research group attribute the loss of control to internal reasons, and they regard the reasons as more stable and global in terms of both performance and loss than the members of the control groups do. In this respect there is no difference between the two genders.

Keywords: sub-clinical depressive syndrome, dysfunctional attitudes, coping strategies, attributional styles 